\title{
Seagrass Sensitivity to Collapse Along a Hydrodynamic Gradient: Evidence from a Pristine Subtropical Intertidal Ecosystem
}

\author{
El-Hacen M. El-Hacen, ${ }^{1,2 *}$ Tjeerd J. Bouma, ${ }^{1,3}$ Laura L. Govers, ${ }^{1,4}$ \\ Theunis Piersma, ${ }^{1,5}$ and Han Olff ${ }^{1}$
}

\begin{abstract}
${ }^{1}$ Conservation Ecology Group, Groningen Institute for Evolutionary Life Sciences, University of Groningen, P.O. Box 11103, 9700 CC Groningen, The Netherlands; ${ }^{2}$ Parc National du Banc d'Arguin (PNBA), Rue Gleiguime Ould Habiboullah, B Nord No 100, B.P. 5355, Nouakchott, Mauritania; ${ }^{3}$ NIOZ Royal Netherlands Institute for Sea Research, Department of Estuarine and Delta Systems, Utrecht University, P.O. Box 140, 4400 AC Yerseke, The Netherlands: ${ }^{4}$ Department of Aquatic Ecology and environmental biology, Institute for Water and Wetland Research (IWWR), Radboud University, Heyendaalseweg 135, 6525 AJ Nijmegen, The Netherlands; ${ }^{5}$ NIOZ Royal Netherlands Institute for Sea Research, Department of Coastal Systems, Utrecht University, P.O. Box 59, 1790 AB Den Burg,
\end{abstract} Texel, The Netherlands

\begin{abstract}
Eutrophication causes tremendous losses to seagrass around the globe. The effects of nutrient loading vary along environmental gradients, and wave forces especially are expected to affect meadow stability, nutrient status, and responses to nutrient supply. Here, we surveyed the pristine subtropical intertidal seagrass system of Banc d'Arguin, Mauritania, to characterise Zostera noltii in terms of morphology (biomass allocation, leaf length and area, rhizome internode length), nutrient content (carbon: $\mathrm{C}$, nitrogen: $\mathrm{N}$, phosphorus: $\mathrm{P}$, iron: $\mathrm{Fe}$, aluminium: $\mathrm{Al}$ ), and patterns in $\delta^{13} \mathrm{C}$ and $\delta^{15} \mathrm{~N}$ across a wide gradient of hydrodynamic conditions. We subsequently assessed tem-
\end{abstract}

Received 30 April 2018; accepted 15 October 2018; published online 2 January 2019

Electronic supplementary material: The online version of this article (https://doi.org/10.1007/s10021-018-0319-0) contains supplementary material, which is available to authorized users.

Author contributions EME, HO, TJB, and TP were responsible for the design of the study. Bathymetric mapping was performed by EME and HO. All authors collected the field data, and EME, HO, LG, and TJB led the statistical analyses. All authors contributed to the final version and gave approval for publication.

*Corresponding author; e-mail: e.h.m.el.hacen@rug.nl poral variability in seagrass stability and nutrient fluxes, as well as responses to experimental fertilisation (pulses of $+\mathrm{N},+\mathrm{P},+\mathrm{N}+\mathrm{P}$ ) on three meadows representing different degrees of waveforce (exposed, intermediate and sheltered). The large-scale survey revealed a marked increase in $\mathrm{N}$ and $\mathrm{P}$ limitation with increasing wave energy. The overall low leaf $\% \mathrm{~N}(1.74 \pm 0.04$; mean \pm se $)$ and $\mathrm{N}: \mathrm{P}$ ratio $(8.67 \pm 0.14)$ suggests that the area is $\mathrm{N}$ limited. Seasonal variation in seagrass cover and biomass showed the exposed site to be the most stable and the sheltered site the least. Variation in $\delta^{15} \mathrm{~N}$ signatures indicates seasonal shifts in $\mathrm{N}$ sources at the exposed site only. Fertilisation with $+\mathrm{N}$ and $+\mathrm{N}+\mathrm{P}$ induced seagrass mortality at the exposed site, while at the sheltered site it was $+\mathrm{P}$ that degraded seagrass. Collectively, our results indicate that with increasing wave forces, the degree of stability of seagrass beds increases, but nutrient limitation and vulnerability to eutrophication increase as well.

Key words: Banc d'Arguin-Mauritania; environmental gradient; eutrophication; fertilisation; hydrodynamic; nutrient limitation; pristine environment; Zostera noltii. 


\section{HighLights}

- The pristine seagrass beds of Banc d'Arguin occur over a wide wave-force gradients

- These gradients were used to assess sensitivity of seagrass to eutrophication

- Nutrient limitation, but also stability, increased under high wave energy

- Seagrass sensitivity to nutrient loading increased with hydrodynamic exposure

\section{INTRODUCTION}

The exploitation of coastal systems has negatively affected most seagrass beds around the world (Short and Wyllie-Echeverria 1996; Orth and others 2006; Waycott and others 2009). Of all humanrelated disturbances, eutrophication-induced mortality is considered the most destructive factor for seagrasses (Burkholder and others 2007). Eutrophication (mainly excess nitrogen) stimulates the growth of phytoplankton, epiphytes and ephemeral macroalgae (Duarte 1995; Viaroli and others 2008), which kill seagrasses through shading and light limitation (Short and others 1995). Eutrophication generally occurs at landscape scales (Green and others 2004), sometimes leading to mass mortality of seagrasses which subsequently provokes sediment suspension (Maxwell and others 2017). The latter will further hinder seagrass recovery (Folmer and others 2012) and may trigger a regime shift (van der Heide and others 2007). In general, sediment dynamics may also hamper longterm seagrass persistence (Suykerbuyk and others 2016).

Potential responses of seagrasses to eutrophication are usually assessed with nutrient addition experiments. Across sites, meta-analyses on the responses of seagrass to experimental fertilisation at small scales (Leoni and others 2008; Östman and others 2016) show that these responses are not uniform across systems (Jiménez-Ramos and others 2017). A possible explanation may be related to differences in hydrodynamic exposure, as hydrodynamics may directly affect nutrient uptake (Morris and others 2008, 2013). However, the assessment of the effect of nutrients enrichment along hydrodynamic gradients remains a major challenge (but see Armitage and others $2005,2011)$. The paucity of ecosystems that are large and untouched enough limit the opportunities for addressing this question at landscape scales.
Hydrodynamics vary in space and time and create environmental gradients at the landscape scale (Paul and Amos 2011). Intertidal seagrass communities are profoundly affected by hydrodynamic forces (Fonseca and Bell 1998; Turner and others 1999; van Katwijk and Hermus 2000; Cornelisen and Thomas 2004; Peralta and others 2006; Vacchi and others 2012). Wave action and tidal flow not only impose physical stress on seagrass, but also spatially and temporally affect sediment dynamics (Hu and others 2015, 2017, 2018) and nutrient supplies (Morris and others 2008, 2013; Malta and others 2017). Global warming is expected to exacerbate the intensity and frequency of the extreme weather events such as floods, droughts and storms (Easterling and others 2000; Jentsch and others 2007; IPCC 2012). Such extreme events, together with accelerating sea-level rise, are likely to affect hydrodynamic regimes and sediment dynamics, and thus seagrass stability (Cardoso and others 2008; Grilo and others 2011; Jeanson and others 2014; Malta and others 2017).

The extensive intertidal flats of Parc National du Banc d'Arguin, Mauritania, West Africa, harbour one of the most pristine and extensive seagrass meadows on Earth (Campredon 2000; Folmer and others 2012; de Fouw and others 2016). Giving its size and clear gradients in wave exposure, the Banc d'Arguin provides an ideal system to experimentally investigate the separate and interactive effects of hydrodynamic and nutrients enrichment on the stability of seagrass beds. The area has three potential external sources of nutrients that could affect its nutrient budget: (1) the active upwelling zone of Cap Blanc (Steinfeldt and others 2015) (2) dust of the Sahara (Neuer and others 2004) and (3) the large number of breeding seabirds (Anderson and Polis 1999). The extent to which these systems may affect the nutrient status of the seagrass beds of Banc d'Arguin is presently unclear.

Owing to its sensitivity to changes in nutrient conditions, seagrass morphology and stoichiometry are increasingly used as ecological indicators to infer coastal ecosystem processes, nutrient limitation as well as an early warning sentinels for regime shifts (Duarte 1990; Grice and others 1996; Fourqurean and others 2007; Burkholder and others 2013). It has been suggested that seagrass leaf $\% \mathrm{~N}$ and \%P contents are indicators of nutrient limitation (Duarte 1990) and nutrient loading (Govers and others 2014b). Biomass allocation (Herbert and Fourqurean 2009; Armitage and others 2011), as well as leaf and rhizomes internode lengths (Marbà and Duarte 1995; Peralta and others 2000; Cabaço and Santos 2007; Balestri and Lardicci 2014), has 
been associated with nutrient availability and sediment dynamics. Leaf isotopic ratios $\left(\delta^{13} \mathrm{C}\right.$ and $\delta^{15} \mathrm{~N}$ ), on the other hand, have been proven to be powerful tracers for the sources of nutrients in the system (Lepoint and others 2004). For instance, abundances of $\delta^{15} \mathrm{~N}$ in the tissues have been widely used to infer the sources of $\mathrm{N}$ in the system (Lepoint and others 2004). Values of $\delta^{15} \mathrm{~N}$ increase when $\mathrm{N}$ originates from an external source rather than being fixed in situ (Schrama and others 2013). Values of $\delta^{13} \mathrm{C}$ tend to decrease with tidal elevation reflecting signals of bicarbonate $\left(\mathrm{HCO}_{3}{ }^{-}\right)$lower on the gradient and signals of atmospheric $\mathrm{CO}_{2}$ higher on (Lepoint and others 2003; Ruesink and others 2015). This trend in $\delta^{13} \mathrm{C}$ values has been shown to occur to Z. noltii in our study area (Clavier and others 2011). Finally, iron (Fe) and aluminium (Al) trace elements proved to be indicators for Saharan dust input into the adjacent marine systems (Kramer and others 2004; Baker and others 2006; Castillo and others 2008).

The objective of this study was to understand how differences in environmental context along a hydrodynamic gradient affect seagrass stoichiometry and stability, and subsequently, the sensitivity to collapse in response to nutrient pulses (that is, mimicked by artificial fertilisation). We combined a snapshot large spatial-scale survey, a 2 year detailed survey of 48 plots, and a field fertilisation experiments at three sites in the hydrodynamic gradient to: (1) characterise the effect of wave energy gradient and distance to nutrient sources (that is, breeding birds) on nine variables from seagrass morphology and stoichiometry as well as two sediment variables; (2) identify the temporal variability in seagrass morphology, stoichiometry, and stability on three sites representing different hydrodynamic regimes (exposed, intermediate and sheltered); and (3) experimentally assess the responses of seagrass to nutrients addition on these sites.

\section{Materials ANd Methods}

\section{Study System}

This study was conducted across the intertidal parts of the Parc National du Banc d'Arguin (PNBA), Mauritania $\left(19-20^{\circ} \mathrm{N}\right.$ and $16-17^{\circ} \mathrm{W}$; Figure 1A). The intertidal system of Banc d'Arguin contains the largest intertidal seagrass beds in Africa $\left(500 \mathrm{~km}^{2}\right.$; Wolff and Smit 1990). The dwarf eelgrass Zostera noltii is the most dominant intertidal species and the main primary producer of the system (Wolff and others 1993). Higher on the intertidal gradient, the opportunistic macroalgae Vaucheria seems to compete with Z. noltii for space and possibly resources, especially in areas with high sedimentation rates. Precipitation is very low $(<100 \mathrm{~mm}$, Ahmedou and others 2008) and the wind is abundant year-round, reaching on average $9 \mathrm{~m} \mathrm{~s}^{-1}$ in May-June and $6 \mathrm{~m} \mathrm{~s}^{-1}$ in November-December with predominately northern winds (Ould Dedah 1993).

\section{Hydrodynamic Gradient and Wave- Energy Calculation}

The open-source software Wave Exposure Model (WEMo, Malhotra and Fonseca 2007) was used as a proxy for chronic hydrodynamic forces at our study sites (263 stations). The model was developed by the National Oceanic and Atmospheric Administration (NOAA) and is implemented in ESRI ArcGIS 9.3 software. WEMo incorporates the surrounding water masses (GIS bathymetric map) and the strength and direction of the wind (separate data file) to calculate fetch length (calculated in 32 compass directions) and then 11 indices related to wave exposure. In order to conduct the exposure index, we first created a bathymetric map for the study area on a $30 \mathrm{~m}$ resolution (Figure $1 \mathrm{~A}$ ) based on a Landsat 8 Satellite Imagery, scene of January 2016 (for description of the technique see, Jagalingam and others 2015). The bathymetric map was calibrated with field depth measurements by Jager (1993) plus extra ground-truthing measurements around Iwik peninsula by Sidi Cheikh and others (Unpub. data). Wind data were obtained for the period 1980-2016 from MERRA product publicly available online (http://disc.sci.gsfc.nasa.gov/mdis c/data-holdings/merra/). Spatial wave-energy distribution $\left(\mathrm{J} \mathrm{m}^{-1}\right)$ and the average wave height $(\mathrm{m})$ were extrapolated to the core intertidal flats of Banc d'Arguin around the island of Tidra by IDW interpolation (Spatial Analyst Tools, ArcGIS) based on the 263 stations simulated by WEMo.

\section{Seagrass Survey and Fertilisation Experiment}

The effect of hydrodynamic gradient on seagrass morphology and stoichiometry as well as sediment characteristics was determined at 160 stations; 90 stations chosen along nine channels with different wave exposure (Figure 1A), and another 70 randomly selected stations. Then, a total of 48 permanent plots $\left(1 \mathrm{~m}^{2}, 16\right.$ plots in 4 blocks per site) were established on three sites representing different wave forces (Table S1) to investigate seagrass 

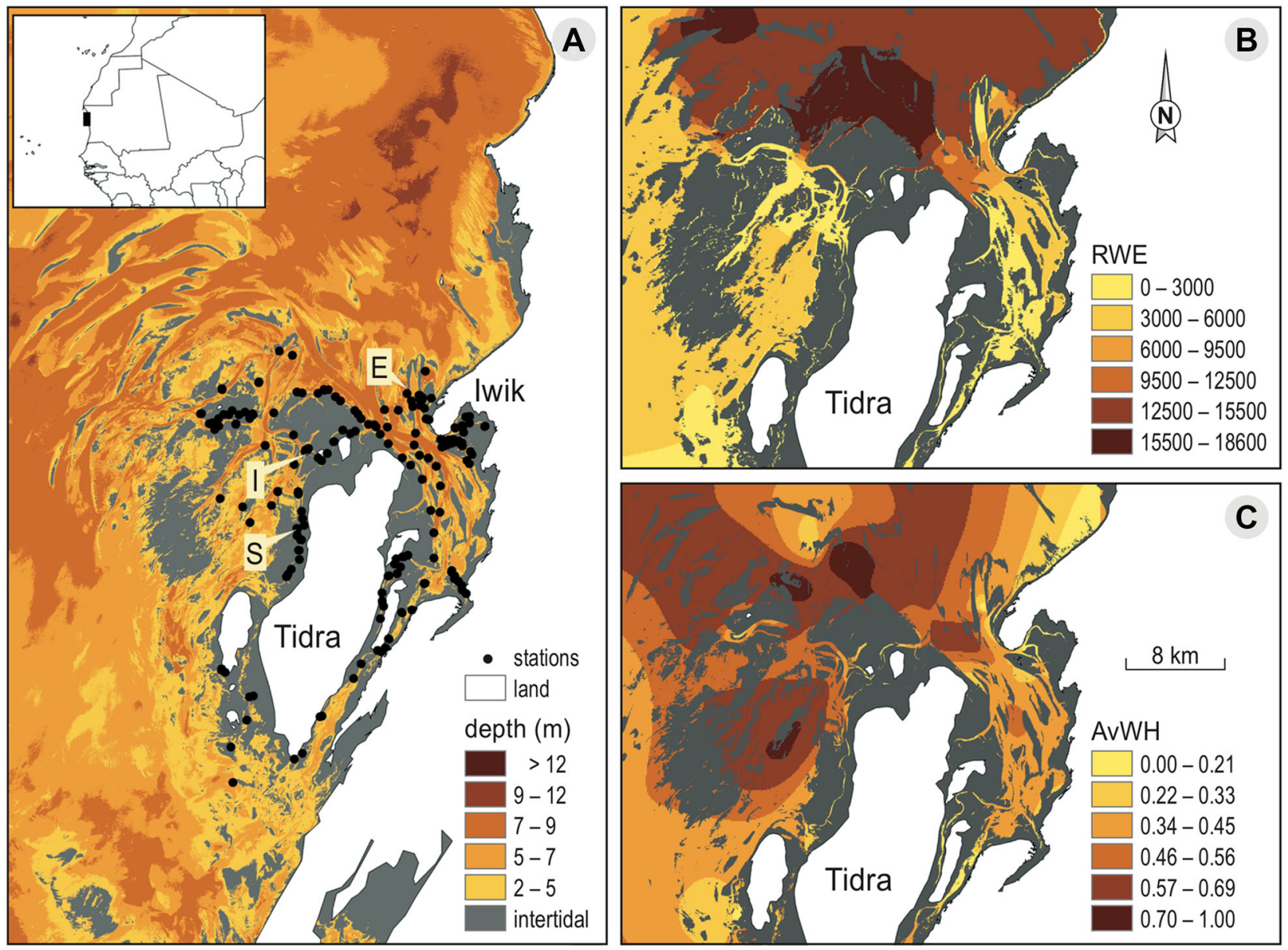

Figure 1. A Detailed bathymetric map of Banc d'Arguin, Mauritania, and the emerging mudflats at low tide (grey) based on Landsat 8 image. Black dots represent the landscape survey sampling stations. Abbreviations of long-term study sites: $\mathrm{E}=$ exposed; $\mathrm{I}=$ intermediate; and $\mathrm{S}=$ sheltered. B Spatial relative wave-energy distribution $\left(\mathrm{RWE}, \mathrm{J}^{-1}\right)$ and $\mathbf{C}$ the average wave height $(\mathrm{m})$ in the core intertidal flats of Banc d'Arguin, obtained by IDW interpolation (Spatial Analyst Tools, ArcGIS, based on 260 stations) of relative wave energy and wave height, respectively, simulated by Wave Exposure Model (WEMo).

temporal stoichiometry, morphology, and stability as well as its responses to experimental fertilisation (Control: $\mathrm{C}$, nitrogen addition: $+\mathrm{N}$, phosphorus addition: $+\mathrm{P}$ and $+\mathrm{N}+\mathrm{P}$ ). Tidal elevation and water temperature were measured in all sites for 1 year using tide-loggers (ReefNet, Sensus Ultra, Canada) equipped with temperature-sensors. No significant difference in elevation and water temperature between study sites was found (Table S1), and therefore, the two variables were not further included in the analysis.

Fertilisation treatments were randomly assigned within each block. Fertilisation was applied in an even manner with the aid of a grid of $10 \times 10 \mathrm{~cm}^{2}$ by injecting the treatment beneath the seagrass shoots into the rhizosphere. For nitrogen treatment, small syringes $(2 \mathrm{~cm}$ in diameter) with the tip cut off were used to inject $350 \mathrm{~g} / \mathrm{m}^{2}$ Osmocote $^{\circledR}$ slow-release granules fertiliser (g:g:g ratio N:P:K 35:0:0) with a release-span of 8-9 months. Phosphorus was applied by injecting (to a $10 \mathrm{~cm}$ depth) high dose of granule hydrated tri-calcium phosphate (" $\mathrm{CaPO}_{4}$ ") solution (400 g in $2 \mathrm{~L}$ of seawater $/ \mathrm{m}^{2}$ ) with $70 \mathrm{~mL}$ syringes (see appendix, Christianen and others 2012). Nitrogen release was estimated as $41 \mathrm{~g} \mathrm{~m}^{2}$ per month, a nutrient loading rate exceeding thresholds that cause eutrophication (Connell and others 2017).Treatments were applied once, and the response of seagrass was assessed 6 month later. The interval was chosen with reference to the release-span of the fertilisers (89 months), and it should also be mentioned that the remoteness of the experimental sites prevented more frequent assessments.

The experimental study of eutrophication through adding nutrients to the water column is 
very difficult in marine ecosystems due to their open nature (for example, due to water exchange through tidal current). For this reason, field studies assessing the effect of eutrophication on seagrasses use sediment fertilisation instead of water column. However, the biggest shortcoming of local sediment fertilisation is that it does not promote ephemeral macroalgae and phytoplankton growth in the water column. Although sediment fertilisation might therefore not represent all aspect of real-life eutrophication events, they still capture several important mechanisms of eutrophication including ammonium toxicity, epiphyte growth and enhanced sulphide production (Burkholder and others 2007).

\section{Sampling and Measurements}

The measurements were conducted in a similar manner at survey stations and the fertilisation plots. Seagrass biomass was sampled in each plot by a cylindrical PVC core $(15 \mathrm{~cm}$ diameter $)$ up to a depth of $20 \mathrm{~cm}$. The collected substrate was sieved over a 1-mm mesh sieve. Above- and belowground seagrass biomass was separated. Morphological parameters (leaf and internode length) were measured on three fresh intact shoot-rhizome samples from each core, and their first ten rhizome internodes were measured to the nearest $0.1 \mathrm{~mm}$ as well as the shoot length. Leaf area (LA) was estimated on photographs taken from the intact shoots with ImageJ software (freely available online). Seagrass cover within each plot was visually estimated on $0-$ $100 \%$ scale using a $10 \times 10 \mathrm{~cm}$ grid. Microphytobenthos (diatoms, cyanobacteria and green algae) densities $\left(\mu \mathrm{g} \mathrm{cm}^{-2}\right)$ were estimated with fluorescence-calibrated device, BenthoTorch (bbe-Moldaenke BenthoTorch, Germany). Other relevant abiotic factors were measured once for each sampling station, including sediment samples to determine median grain size (D50) and organic matter content (loss of ignition at $500^{\circ} \mathrm{C}$ ). Distance to seabird colonies was measured in Google Earth.

In the laboratory, the above- and belowground biomass was dried until constant weight at $70^{\circ} \mathrm{C}$ for $48 \mathrm{~h}$, weighed and then ground for nutrients and stable isotope analyses. To assess seagrass nutrient status and isotopic signals, dried and grinded leaf material was used to determine the percentage of carbon $(\% \mathrm{C})$, nitrogen $(\% \mathrm{~N}), \delta^{15} \mathrm{~N}$ and $\delta^{13} \mathrm{C}$ with an elemental analyser (Type NA 1500 Carlo Erbo Termo Fisher Science, USA), coupled to a spectrometer (Thermo Finnigan Delta Plus, USA). Total phosphorus $(\% \mathrm{P})$, iron $(\% \mathrm{Fe})$, and aluminium $(\% \mathrm{Al})$ in leaf tissue were measured on an induc- tivity-coupled-plasma emission spectrophotometer (ICP) (Spectroflame, Spectro Inc), after digestion of dried material with nitric acid and hydrogen peroxide. Grain size was determined on freeze-dried and sieved ( $1 \mathrm{~mm}$ mesh) samples by laser diffraction on a Malvern particle size analyser (Master 2000).

\section{Statistical Analyses}

We sought to characterise the environmental gradient related to hydrodynamic forces using ordination approaches. Detrended correspondence analysis (DCA) and principal component analysis (PCA) were considered to summarise the environmental gradient along the wave-energy index and to identify the main variables that might affect the seagrass response to fertilisation. Gradient lengths from DCA were very short $(<0.1)$, suggesting that PCA analysis was more appropriate (Lepš and Šmilauer 2003). Thus, only PCA results are presented. Seagrass morphology (leaf area (LA), leaf length, leaves density, below-to-aboveground biomass ratio), stoichiometry $(\% \mathrm{~N}, \% \mathrm{P}, \% \mathrm{Fe})$, and isoscapes $\left(\delta^{15} \mathrm{~N}\right.$, and $\left.\delta^{13} \mathrm{C}\right)$ as well as sediment characteristics (D50, OM) from the 160 stations were used for the PCA. Prior PCA analysis, some variables were $(\log +1)$ transformed to ensure normality and homogeneity of each variable. The circle of equilibrium contribution was used to visualise the significance of the variables. This circle defines a region beyond which variables can be interpreted with great confidence (Legendre and Legendre 1998).

The spatial patterns in variables that might affect the response to fertilisation (seagrass stoichiometry, sediment OM, and grain size) were examined with linear regression to test for the ability of RWE to predict changes and trends in these variables. Furthermore, descriptive results of seagrass $\% \mathrm{~N}, \% \mathrm{P}$, $\mathrm{N}: \mathrm{P}, \delta^{15} \mathrm{~N}$, sediment $\mathrm{OM}$ and grain size were presented as contour maps generated using a gridding interpolation (Kriging technique in Spatial Analyst Tools, ArcGIS) based on 160 stations to describe spatial trends at a system scale.

The seasonal (winter vs. spring) changes of seagrass' morphology, stoichiometry and stability along the exposure gradient (exposed, intermediate and sheltered) were analysed with two-way analysis of variance (ANOVA). Parametric assumptions were checked on the residuals, and data were transformed when necessary. To assess the seasonality without effect from the fertilisation treatments, only controls and samples collected in 
January 2013 (just before nutrients addition) and May 2015 (2 years later) were used for the analysis.

To compare the magnitude of differences in seagrass response to fertilisation across an exposure gradient, effect size analysis was estimated as the natural $\log$ of response ratios, $L R R=\log$ (treatment/control) calculated following Hedges and others (1999). The log response ratio was chosen over other methods because its high capacity to detect true effects and their robustness in small sample sizes (Lajeunesse and Forbes 2003). Mean effect sizes \pm CI of treatments were calculated using the R package "Metafor" (Viechtbauer 2010) and were considered significant if the $95 \% \mathrm{CI}$ did not overlap with zero.

All statistical analyses were conducted with the statistical software R (version 3.4.3, R Development Core Team 2017, Vienna, Austria; available at: http://www.R-project.org).

\section{ReSUlts}

\section{Wave Exposure Across the Banc d'Arguin and at the Fertilisation Sites}

Across the Banc d'Arguin, relative wave energy (RWE) showed great variability (Figure 1B), with an overall average \pm se of $2681 \pm 84 \mathrm{~J} \mathrm{~m}^{-1}$. There was a strong north to south gradient, ranging from 23,031 in the north to $0 \mathrm{~J} \mathrm{~m}^{-1}$ at the isolated inner intertidal flats (Figure 1B). The eastern side of the island of Tidra showed a gradual south-ward decrease in wave energy (Figure 1B), whereas the western side seemed to experience more heterogeneity in wave action due to the complexity of the mudflats and water bodies (Figure 1A, C). The selected sites for the fertilisation experiment had RWE's of 3639 in the exposed site, 1629 for the intermediate and $676 \mathrm{~J} \mathrm{~m}^{-1}$ for the sheltered site. Additional information on the initial conditions of these sites including leaf morphology and stoichiometry, sediment nutrient content, bear-bed shear stress, and water temperature is summarised in Table S1.

\section{Main Environmental Gradient Characteristics in Banc d'Arguin}

PCA ordination revealed a subtle environmental gradient related to hydrodynamic forcing, as indicated by the RWE and sediment characteristic such as median grain size (D50) and organic matter content (OM) along the first axis (Figure 2) and gradient related to tidal elevation represented by seagrass isotopic ${ }^{13} \mathrm{C}$-values $\left(\mathrm{d}^{13} \mathrm{C}\right)$ and seagrass

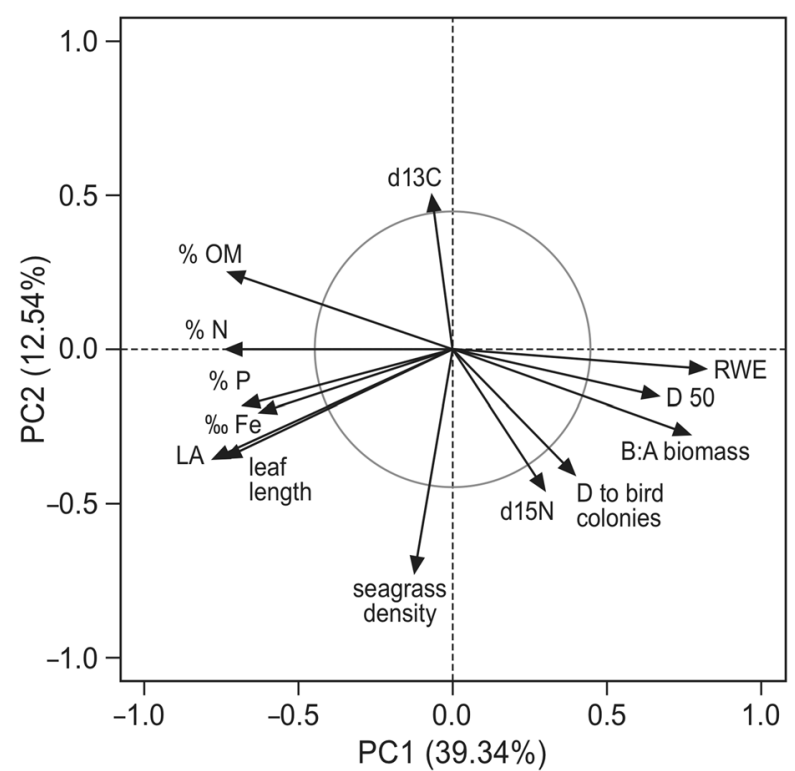

Figure 2. Plot of the first two dimension of principal component analysis (PCA) for sediment properties, seagrass traits, and wave-energy gradient. RWE = relative wave energy $\left(\mathrm{J} \mathrm{m}^{-1}\right)$, D50 $=$ sediment median grain size, $\mathrm{B}: \mathrm{A}=$ seagrass belowground $/$ aboveground biomass ratio, $\mathrm{D}$ to bird colonies $=$ distance to the nearest birds' breeding colonies or major roosting sites $(\mathrm{m}), \mathrm{d}^{15} \mathrm{~N}=$ leaf nitrogen isotope, $\% \mathrm{P}=$ leaf phosphorus content, seagrass density = leaves density $\left(\# \mathrm{~m}^{2}\right)$, leaf length $=$ average leaves length $(\mathrm{mm}), \mathrm{LA}=$ average leaf area $\left(\mathrm{cm}^{2}\right), \% \mathrm{~N}=$ leaf nitrogen content, \% Fe = leaf iron content, \% OM = sediment organic matter content and $\mathrm{d}^{13} \mathrm{C}=$ leaf carbon isotope. Variables with heads outside of the grey equilibrium circle significantly contribute to the ordination diagram (Legendre and Legendre 1998).

density along the second axis (PCA2 in Figure 2). All variables extend beyond the circle of equilibrium contribution, meaning that they all contributed significantly to the PCA (Figure 2). Along the first axis (39\%), RWE showed a strong positive correlation with both sediment grain size and DW below-to-aboveground ratio. These variables showed strong inverse correlation with sediment $\mathrm{OM}$, leaf $\% \mathrm{~N}$, leaf $\% \mathrm{P}$, leaf $\% \mathrm{Fe}$, leaf length and LA. The second PCA axis $(13 \%)$ was associated with a gradient defined by seagrass density and isotopic values having denser seagrass beds at one end and a more sparse/algal dominated at the other (Figure 2). Seagrass density correlated positively with leaf $\delta^{15} \mathrm{~N}$ and distance to birds' breeding colonies, and negatively with leaf $\delta^{13} \mathrm{C}$ (Figure 2). The first two axes of the PCA accounted for $53 \%$ of the total variation in sediment and seagrass properties at the landscape scale. 


\section{Spatial Variability Across the Wave- Exposure Gradient}

Leaf \% $\mathrm{P}$ content decreased as RWE increased $\left(r^{2}=0.25, P<0.001\right.$, Figure S1A). The northern part of the study area (that is, the area north of the island of Tidra), on average showed a seagrass \% $\mathrm{P}$ of $0.18 \pm 0.02 \mathrm{mg} \mathrm{P} \mathrm{g}^{-1}$, whereas the inner southern intertidal flats had $0.25 \pm 0.03 \mathrm{mg} \mathrm{P} \mathrm{g}^{-1}$ (Figure $3 \mathrm{~A}$ ). Leaf $\% \mathrm{~N}$ content also decreased as RWE increased $\left(r^{2}=0.37, P<0.001\right.$, Figure S1B). On average $( \pm \mathrm{se})$, the northern part of the study area had $1.5 \pm 0.2 \mathrm{mg} \mathrm{N} \mathrm{g}^{-1}$, whereas the inner intertidal flats had $2.08 \pm 0.3 \mathrm{mg} \mathrm{N} \mathrm{g}^{-1}$. The western part of the study site, situated at the ocean side of the island of Tidra, had relatively high $\% \mathrm{~N}$ compared with sites on eastern side of Tidra (Figure $3 \mathrm{~B})$. N:P ratios were very low and ranged from 3.7 to $16.4 \%$ (with an average of $8.7 \% \pm 2.19$ ) (Figure 3C), indicating that the system is more Nlimited than P-limited. Leaf $\delta^{15} \mathrm{~N}$ values showed more complex and patchy spatial patterns, with different pockets of high values spreading across the study area without any clear pattern along the wave-energy gradient (Figure 3D). Values of $\delta^{15} \mathrm{~N}$ ranged from 0.02 to $5.73(2.4 \pm 0.9)$, suggesting the existence of multiple sources of $\mathrm{N}$ from different trophic levels. Sediment grain size and $\mathrm{OM}$ content were spatially decoupled, with coarser sediments containing less organic matter (Figure $3 \mathrm{E}, \mathrm{F})$. Sediment $\mathrm{OM}$ decreased with increasing RWE $\left(r^{2}=0.25, P<0.001\right.$, Figure S1C), whereas grain size increased as REW increased $\left(r^{2}=0.31\right.$, $P<0.001$, Figure S1D).

\section{Seasonal Variability Along the Wave- Exposure Gradient}

Leaf macronutrient ( $\mathrm{N}$ and $\mathrm{P}$ ) contents were generally higher in winter than in spring, and the largest seasonal contrast was found in the most sheltered site with a strong peak in winter and a dip in spring (Table 1; Figure 4A, B). Micronutrient (Fe and $\mathrm{Al}$ ) leaf concentrations, on the other hand, were generally higher during spring compared to winter and thus showed a strong opposite trend to macronutrients between seasons (Table 1; Figure 4C, D). Seagrass stability, defined as low variability in cover over time, increased with wave exposure (Table 1; Figure 4E). Although seagrass cover did not differ significantly between seasons, there was a marked increase during spring at the exposed and intermediate sites and a decrease at the sheltered site (Figure 4E). Macroalgae Vaucheria cover, on the other hand, differed signifi- cantly between seasons, with an increase during winter compared to spring across the sheltered and intermediate sites (Table 1; Figure 4F). During our survey, Vaucheria was never found at the exposed site.

Seagrass below-to-aboveground biomass ratios were significantly lower during spring than winter, and the difference between the seasons seems to increase from the more exposed site to the more sheltered one (Table 1; Figure 4G). Microphytobenthos biomasses showed no significant seasonal trend at any site, and differed between sites, with the exposed site having the lowest biomass (Table 1; Figure $4 \mathrm{H}$ ).

Leaf $\delta^{13} \mathrm{C}$ and $\delta^{15} \mathrm{~N}$ signatures demonstrated a unique temporal pattern per site (Figure 5). Nitrogen isotopes only significantly differed between seasons at the exposed site, suggesting the existence of a seasonal change in the source of $\mathrm{N}$ at this area (Table 1; Figure 5). Carbon isotope signatures differed between seasons only at the intermediate site, indicating a seasonal shift in inorganic carbon sources (Table 1; Figure 5). The two isotope signatures did not differ significantly between seasons at the most sheltered site (Table 1; Figure 5). The exposed and sheltered sites had significantly different leaf $\delta^{13} \mathrm{C}$ values throughout the survey (Table 1; Figure 5), indicating that the two sites use different sources of inorganic carbon.

\section{Responses of Seagrass to Fertilisation Along the Wave-exposure Gradient}

Overall, the magnitude responses of seagrass to nutrient treatments $(+\mathrm{N},+\mathrm{P}$, and $+\mathrm{N}+\mathrm{P})$ differed between sites (Figure 6). Seagrass cover showed a distinct response to $\mathrm{N}$ additions $(+\mathrm{N}$ and $+\mathrm{N}+\mathrm{P}$ ) at the exposed site, where seagrass died in response to these treatments (Figure 6A). At the sheltered site, however, it was + P that significantly decreased seagrass cover (Figure 6A). The seagrass cover of the intermediate site was not significantly affected by any treatment, although $+\mathrm{P}$ led to a marginal increase in cover (Figure 6A). Seagrass above- and belowground biomasses were significantly decreased by $\mathrm{N}$ additions $(+\mathrm{N}$ and $+\mathrm{NP})$ at the exposed and intermediate sites, whereas the treatments did not seem to affect the biomass at the sheltered site (Figure 6B, C). Microphytobenthos biomass significantly increased in both $\mathrm{P}$ treatments $(+\mathrm{P}$ and $+\mathrm{NP})$ at the sheltered site (Figure 6D) and was only boosted by $+\mathrm{NP}$ at the intermediate site. Microphytobenthos biomass at the exposed site was not affected by any treatment (Figure 6D) . 

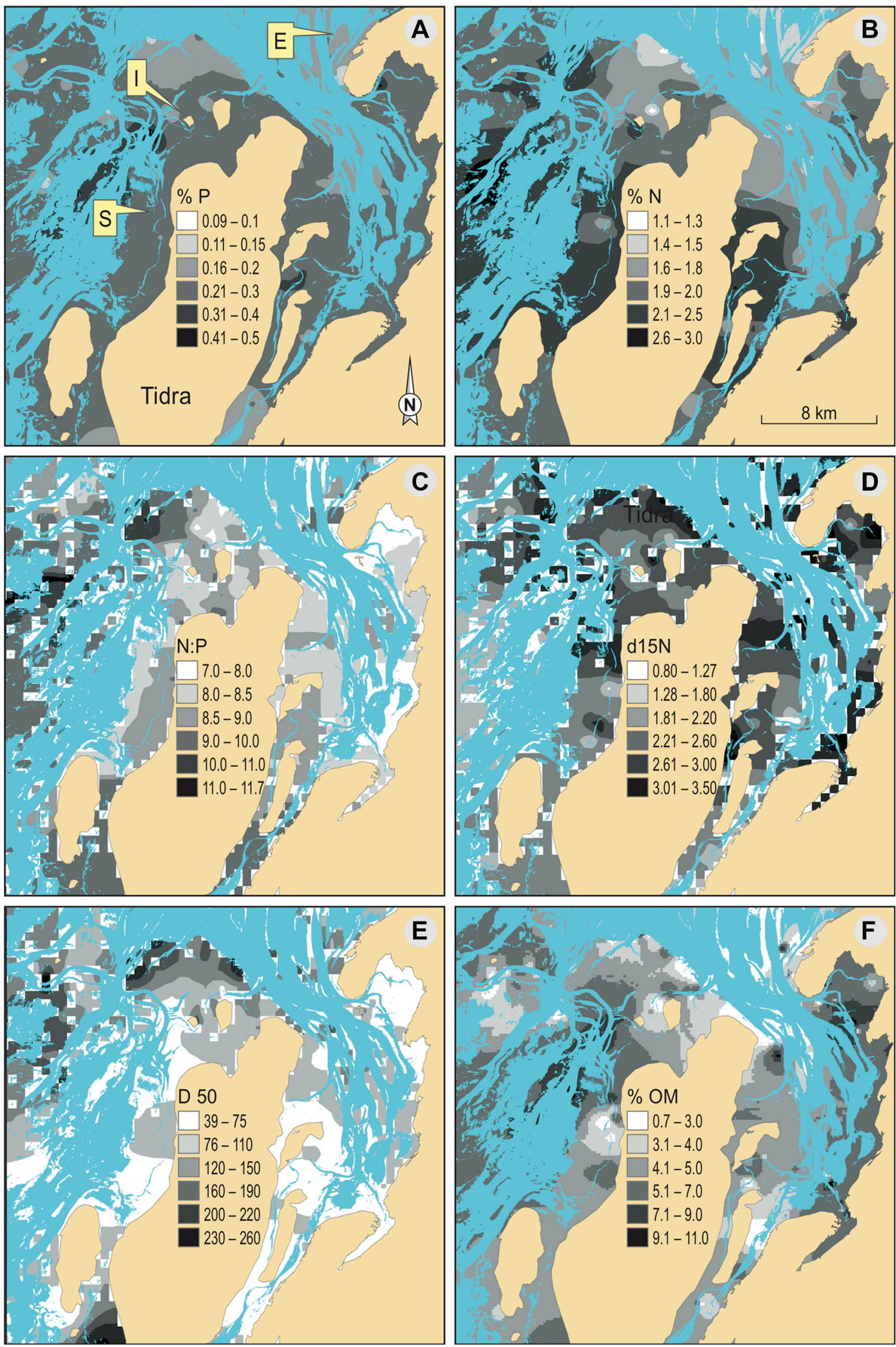
4Figure 3. Spatial patterns of averaged seagrass stoichiometry and sediment condition across the Banc d'Arguin, Mauritania, using a gridding interpolation (Kriging technique in Spatial Analyst Tools, ArcGIS) based on data collected from 160 stations across its intertidal flats (see Figure 1). A Seagrass \% Phosphorus (P) distribution with darker areas indicates higher $\mathrm{P}$ concentrations; B leaf \%Nitrogen $(\mathrm{N})$; C leaf N:P ratio; D Seagrass $\delta^{15} \mathrm{~N}$ values; $\mathbf{E}$ Sediment median grain size (D50); and F Sediment organic matter content (OM).

\section{Discussion}

Nutrient overloads have repeatedly been considered the most destructive factor for seagrass, negatively affecting the stability (that is, little deviation from the average states) of seagrass meadows worldwide (Burkholder and others 2007). Nonetheless, the extent to which hydrodynamic forces may affect seagrass sensitivity to nutrient loading is still unclear. Using a natural wave-exposure gradient, we quantified the spatial and temporal status of seagrass stoichiometry, morphology, and stability and subsequently examined how this gradient affected the responses of Zostera noltii to fertilisation. We showed that: (1) hydrodynamic gradient had strong spatial and temporal effects on seagrass nutrient status and stability, with increasing nutrient limitation and stability with increasing wave energy; (2) the magnitude effect of fertilisation on seagrass varied tremendously across the wave exposure, with the most exposed site being most sensitive to biomass loss due to fertilisation and the sheltered one being least sensitive.

\section{Environment Gradient Characteristics}

Seagrass leaf nutrient content $(\mathrm{N}, \mathrm{P}, \mathrm{Fe}, \mathrm{Al})$, leaf morphology, biomass, sediment grain size, and sediment organic matter all showed strong direct correlations with the wave energy gradient (PCAl; Figure 3). The observed increase in below-toaboveground ratio with exposure indicates that seagrass increasingly invest in anchoring strength. In areas of low water velocity and high sediment deposition, seagrass seems to invest more in their light-harvesting compartment, the leaves. These results are in agreement with reported observational and experimental findings along intertidal gradients elsewhere (Marbà and Duarte 1995; Peralta and others 2000, 2006; Cabaço and Santos 2007; Hovey and others 2012; Balestri and Lardicci 2014).

Greater investment in belowground system holds two benefits for seagrass in high velocity areas: the complex rooting system will ensure seagrass persistence (for example, against erosion and leaf detachment; Peralta and others 2006) and nutrient acquisition from the generally sandy and nutrientpoor sediments (Peralta and others 2000). Simultaneously, investing more in aboveground biomass in low-wave-energy areas also provides twofold benefits: seagrasses can thus cope with sediment deposition and win the competition with the opportunistic macroalgae Vaucheria, characteristic of sheltered areas (Figure 4F). Attenuation of wave action by more leaves (Bouma and others 2005) could also affect seagrass indirectly through setting the background sediment characteristics such as silt and OM contents (Bouma and others 2007). These

Table 1. Results of the Analysis of Variance (Two-way ANOVA) of the Mean Effects of Site and Season and their Interactions on the Morphology and Stoichiometric of Seagrass and its Associated Microphytobenthos

\begin{tabular}{|c|c|c|c|c|c|c|c|c|c|}
\hline \multirow[t]{2}{*}{ Source of variations } & \multicolumn{3}{|c|}{ Season } & \multicolumn{3}{|c|}{ Site } & \multicolumn{3}{|c|}{ Season/site } \\
\hline & $d f$ & MS & $F$ & $d f$ & $M S$ & $F$ & $d f$ & $M S$ & $F$ \\
\hline Leaf total N (\%) & 1 & 2.7 & $28.6^{* * *}$ & 2 & 1.82 & $19.2 * * *$ & 2 & 0.94 & $9.9 * * *$ \\
\hline Leaf total P (\%) & 1 & 0.01 & $12.7 * * *$ & 2 & 0.005 & $3.81^{* *}$ & 2 & 0.004 & $3.63 *$ \\
\hline Leaf total Fe (\%) & 1 & 13.6 & $91.05 * * *$ & 2 & 2.65 & $17.8^{* * *}$ & 2 & 0.9 & $6^{* *}$ \\
\hline Leaf total Al (\%) & 1 & 7.8 & $41.2^{* * *}$ & 2 & 2.6 & $13.8^{* * *}$ & 2 & 1.1 & $5.7^{* *}$ \\
\hline Seagrass cover & 1 & 0.06 & $0.3^{\mathrm{ns}}$ & 2 & 1.8 & $10.1 * * *$ & 2 & 0.4 & $2.3^{\mathrm{ns}}$ \\
\hline Vaucheria cover & 1 & 0.45 & $9.4^{* * *}$ & 2 & 1.14 & $24.1 * * *$ & 2 & 0.15 & $3.15^{*}$ \\
\hline B/A biomass ratio & 1 & 42.1 & $57.9 * * *$ & 2 & 4.5 & $6.17 * *$ & 2 & 1.82 & $2.5^{\mathrm{ns}}$ \\
\hline Microphytobenthos biomass & 1 & 0.2 & $0.6^{\mathrm{ns}}$ & 2 & 6 & $12.3 * * *$ & 2 & 0.5 & $1.1^{\mathrm{ns}}$ \\
\hline Leaf $\delta^{13} \mathrm{C}$ & 1 & 0.82 & $1.8^{\mathrm{ns}}$ & 2 & 5.9 & $12.9 * * *$ & 2 & 1.4 & $2.9 *$ \\
\hline Leaf $\delta^{13} \mathrm{~N}$ & 1 & 0.24 & $3.1^{*}$ & 2 & 1.6 & $1.8^{\mathrm{ns}}$ & 2 & 1.1 & $3.7^{*}$ \\
\hline
\end{tabular}

Bold characters highlight statistically significant differences. B/A represents seagrass belowground/aboveground biomass. Significant difference levels, ns $=P>0.05$, $*=P<0.05, * *=P<0.01$, and $* * *=P<0.001$. 

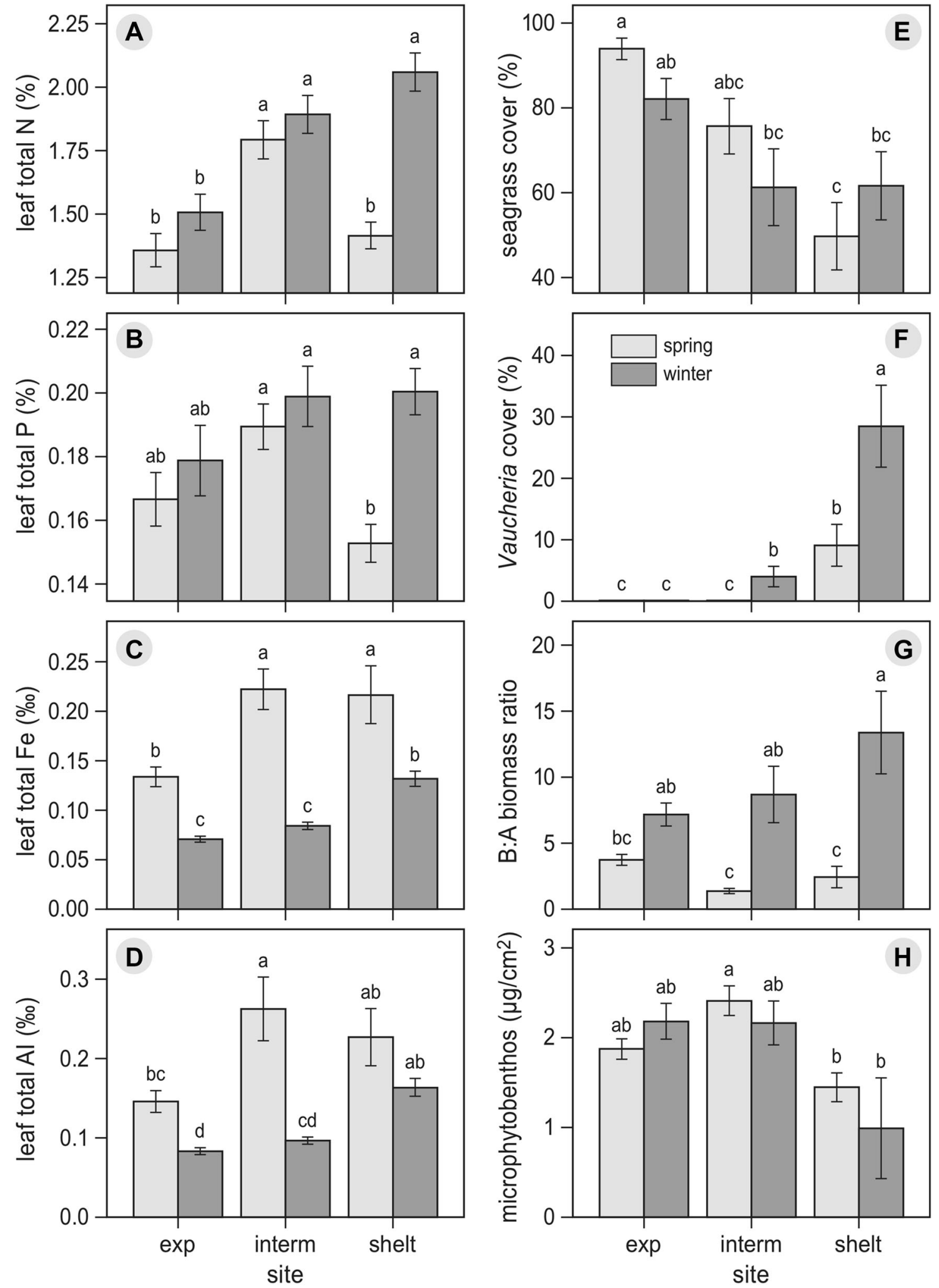
4Figure 4. Bar-plots of the seasonal variations in seagrass A leaf \%Nitrogen, B leaf \% Phosphorus, C \% leaf Fe, D $\%$ leaf $\mathrm{Al}, \mathbf{E}$ seagrass cover, $\mathbf{F}$ vaucheria cover, G belowground/aboveground biomass, and $\mathbf{H}$ associated microphytobenthos in the different hydrodynamic regime sites $(\operatorname{Exp}=$ exposed, Interm $=$ intermediate, Shelt $=$ sheltered $)$. Different colours indicate different sampling period (winter vs. spring). All bars show mean $\pm \mathrm{SE}$; significant differences between seasons as well as sites are depicted by different lower-case letters (2-way ANOVA followed by post hoc Tukey tests, where $P<0.05$ is significant).

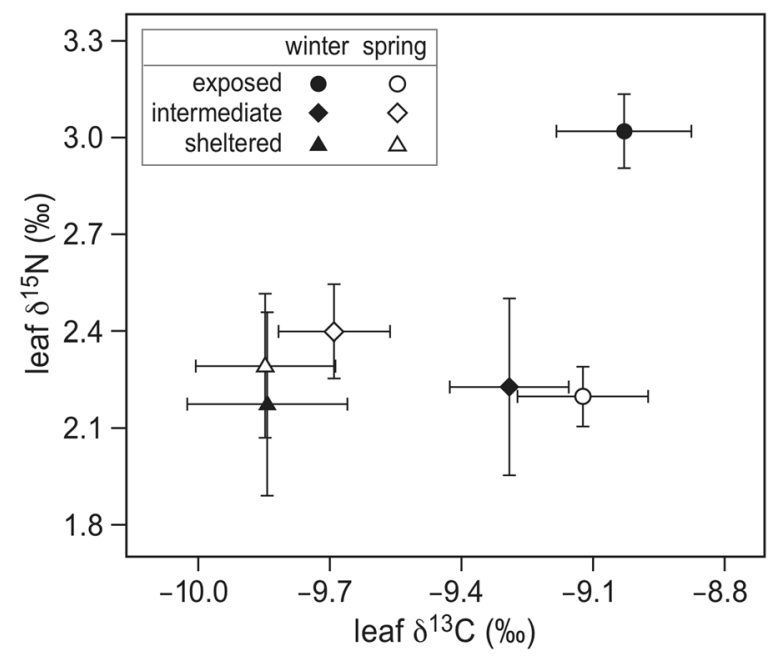

Figure 5. Seasonal variation in stable carbon $\left(\delta^{13} \mathrm{C}\right)$ and nitrogen $\left(\delta^{15} \mathrm{~N}\right)$ isotopic values of Zostera noltii leaves sampled in sheltered (triangles), intermediate (squares), and exposed (circles) seagrass beds in Banc d'Arguin, Mauritania. Open symbols represent spring samples, while the filled symbols represent the winter ones. Values are mean \pm SE.

characteristics have been shown to play an important role in the stability of seagrass in Banc d'Arguin through a negative feedback loop between seagrass density, grain size and OM content (Folmer and others 2012).

\section{Spatial Variability Along the Environment Gradient}

Nutrient concentrations in the leaves decreased with increasing wave energy. The vast majority of the measurements of leaf $\mathrm{N}$ content scored way below the $1.8 \% \mathrm{~N}$ threshold suggested by Duarte (1990) to represent N-limitation. In addition, the spatial patterns of the relative importance of $\mathrm{N}$ to $\mathrm{P}$ ( $\mathrm{N}: \mathrm{P}$ ratio) in limiting productivity also indicate an $\mathrm{N}$ rather than $\mathrm{P}$ limitation across the Banc d'Arguin ecosystem. N:P ratios less than $25-30$ are consid- ered to reflect $\mathrm{N}$-limitation as well (Duarte 1990; Armitage and others 2005; Fraser and others 2012; Burkholder and others 2013). In fact, leaf \%N content found in our study site are among the lowest reported for $Z$. noltii in any of the studied systems (Pérez-Lloréns and Niell 1993; Brun and others 2002, 2003; Marbà and others 2002; Peralta and others 2005; Cabaço and others 2009; Castro and others 2009; Holmer and others 2016). The transport of the rich fine-sediment from more exposed to more sheltered areas, bringing an additional nutrient input to the latter one and impoverishing the exposed sites, may well explain the relative decrease in nutrient concentrations with increasing wave action.

\section{Seasonal Variability Along the Environment Gradient}

In the 2 years of monitoring, biomass allocation, leaf isotopic signals, and leaf nutrient contents strongly varied between sites (exposed, intermediate, sheltered) as well as between season (winter vs. spring). Biomass seemed to follow the seasonal variations in the availability of macronutrients, whereas seagrass cover was mainly site-dependent and appeared to follow seasonal changes in the micronutrients (Figure 4). The observed increase in seagrass cover during spring at the exposed site follows the seasonal growth pattern of $Z$. noltii at Banc d'Arguin described by Vermaat and Verhagen (1996). The increase in cover during winter at the sheltered site (Figure 4E) is different from areas further north, where Z. noltii is known to loose most of its aboveground biomass during the course of winter (Pérez-Lloréns and Niell 1993; PergentMartini and others 2005).

The observed decoupled seasonal leaf macronutrient and micronutrient contents as well as the seasonal seagrass cover change (Figure 4) indicate seasonal nutrient-cycle-driven phenomena and could reflect changes in atmospheric (dust) and/or oceanographic forces (upwelling). Banc d'Arguin lies between year-round very active upwelling zone (Gabric and others 1993), and the Sahara that is known to supply large amount of dust to adjacent systems (Goudie and Middleton 2001). The process of energy flow from the upwelling zone to Banc d'Arguin inner intertidal system, however, lacks empirical evidences and both systems seem not to exchange water masses (Sevrin-Reyssac 1993). Nevertheless, an episodic flow of nutrient might occur during the intense storms driven from the north-west and affect the northern most exposed part of the area (Carlier and others 2015). The 


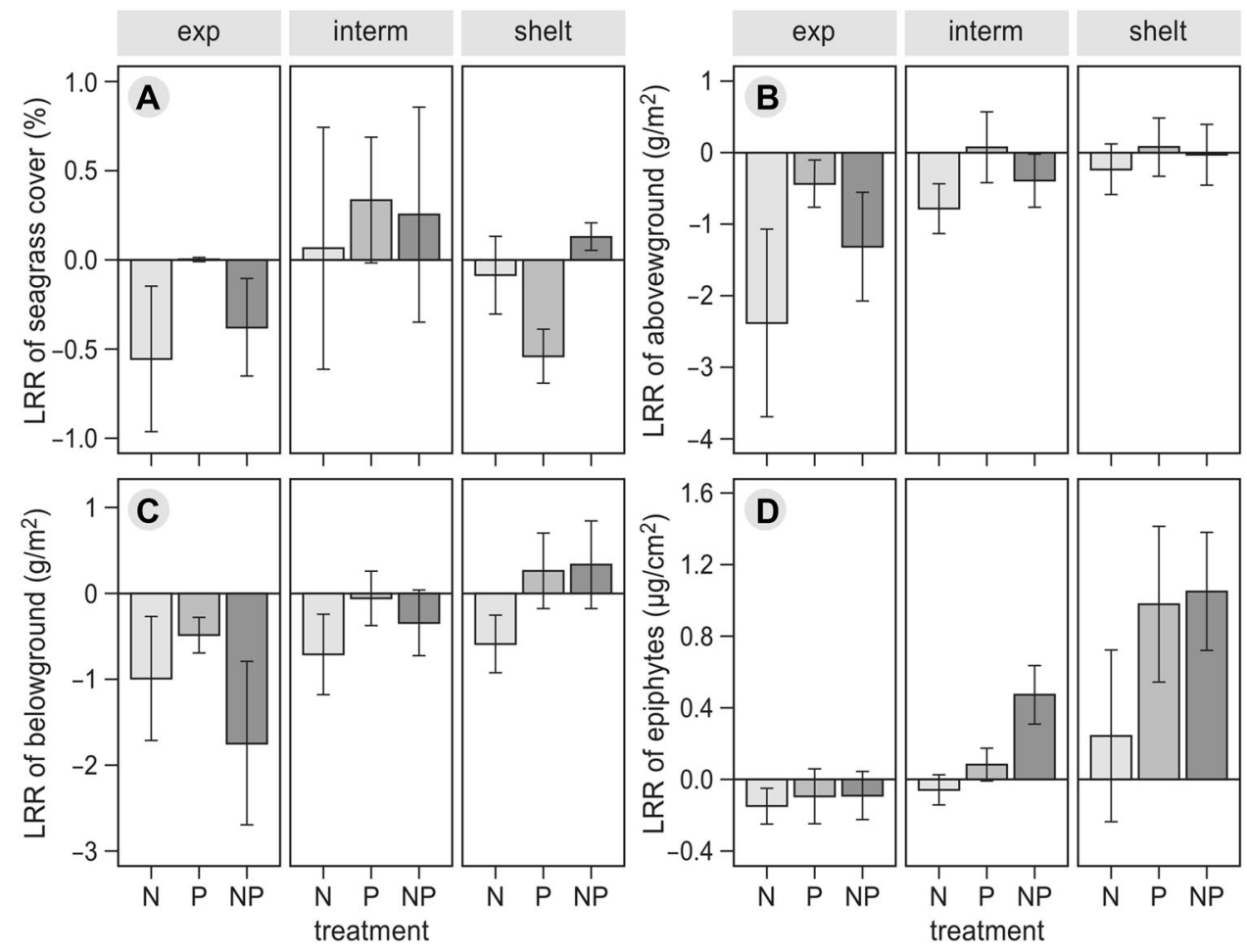

Figure 6. Responses of A seagrass cover, B aboveground biomass, C belowground biomass, and D microphytobenthos densities to nutrient addition by nitrogen $(\mathrm{N})$, phosphorus $(\mathrm{P})$, and both $(\mathrm{NP})$ in three different sites $($ Exp $=$ exposed, Interm $=$ intermediate, Shelt $=$ sheltered) representing different wave-energy forces. The bars represent mean effect sizes ( $\log$ response ratios, LRR) with $95 \%$ CI. The zero line indicates no effect, and the significance of mean effects is determined when the $95 \%$ confidence interval does not overlap zero.

episodic Saharan dust storms, on the other hand, are known to affect nutrient budgets of the recipient systems (Neuer and others 2004).

In view of the seasonal influence of dust and upwelling on nutrient fluxes, strong temporal and seasonal changes in seagrass morphology and stoichiometry in Banc d'Arguin are expected. Our leaf isotopic signature data (Figure 5), as well as trace elemental content $(\mathrm{Fe}, \mathrm{Al})$, indeed support the idea of connectivity between Banc d'Arguin exposed flats to an external source of energy that is affecting its temporal and spatial nutrient status. Fluxes of nutrients associated with episodic dust storms and/ or upwelling intense events may increase in the future, with climate change projections suggesting that the intensity and frequency of the extreme weather events such as floods, drought and storms will increase (Easterling and others 2000; Jentsch and others 2007; IPCC 2012). Thus, predicting the response of seagrass beds to increased episodic nutrient fluxes along environmental gradient should be a research priority.

\section{Responses of Seagrass to Fertilisation Along the Environment Gradient}

The responses of Z. noltii to $\mathrm{N}$ - and P-fertilisation exhibited strong site-element-specific variation: with the strongest negative response (mortality) to $\mathrm{N}$ and $\mathrm{N}+\mathrm{P}$ addition at the most exposed site (Figure 6). This is surprising as this area showed strong signals of $\mathrm{N}$-limitation (leaf $\% \mathrm{~N}<1.5$ ). This means that where $\mathrm{N}$-limitation is severe, sensitivity to high nutrient loads is also high. In contrast, seagrass growing in the more sheltered site only responded to $\mathrm{P}$ addition by biomass loss. The mortality in response to $\mathrm{N}$-addition at the exposed site may be due to a combination of excessive $\mathrm{N}$-loads and efficiency in nutrient uptake. Excess $\mathrm{N}$-loads are known to induce seagrass mortality through ammonium $\left(\mathrm{NH}^{4+}\right)$ toxicity (Santamaría and others 1994; van Katwijk and others 1997; Brun and others 2002; Govers and others 2014a). Exposed plots treated with $+\mathrm{N}$ might have received high $\mathrm{NH}^{4+}$ levels at once due to high diffusion rate across 
sediment-water interface in the coarser sediment (Huettel 2001; Burdige 2006). Furthermore, seagrasses in high velocity conditions have high ammonium uptake efficiency owing to a reduction in thickness of the diffusion boundary layer of the leaves (Koch 1994; Hurd and others 1996; Cornelisen and Thomas 2006). Thus, high leaf nutrient uptake efficiency and high sediment-surface exchange rate at the exposed site may have led to an excessive toxic $\mathrm{NH}^{4+}$ accumulation in the leaves (van der Heide and others 2008).

As we did not do pore-water ammonium measurements, our ability to pin down the cause of the die-offs at the exposed site is limited. In contrast, high $\mathrm{P}$-loads do not generate toxic effects in seagrasses, nor in any other plants (Touchette 2000; Marschner 2012). Negative effects of P-fertilisation on seagrass biomass can generally be attributed to a secondary response: P-stimulated algal and epiphyte blooms that may outcompete seagrasses (Burkholder and others 2007). Indeed, we found an increase in algal biomass at the sheltered site (Figure 6D). In contrast, we did not find a similar algal response in the P-fertilisation treatment at the other sites. This difference may be explained by the different hydrodynamics of the two sites, where the added $\mathrm{P}$ had less effect on $\mathrm{P}$ concentrations in the water column in the exposed site. Also, hydrodynamic is expected to affect the uptake rates of nutrients by seagrass and algae (Koch 1994): increasing flow rates reduces the thickness of the diffusive boundary layer, which then leads to a higher rate of nutrient uptake (Koch 1994; Thomas and others 2000; Morris and others 2008, 2013). These studies have shown that ammonium uptake by seagrass communities correlates positively with water velocity around the leaves. However, injecting the nutrients directly into the pore-water sphere is likely to reduce the extent by which water velocity and tidal amplitude can dilute the nutrient concentrations (Huettel 2001; Santos and others 2012). Our experiment does not reveal the mechanisms by which eutrophication drive the interactions between seagrass and algae. Instead, the significance of this nutrient addition experiment is that it shows how wave forces and nutrient conditions affect the outcomes of nutrient loading along an environmental stress gradient.

The intermediate site showed inconsistence morphologic and stoichiometric responses to fertilisation suggesting the presence of a factor other than the artificial fertilisation affecting nutrient availability for seagrasses. The intermediate site occurs close to the island of Nair, a breeding site for hundreds of seabirds that could bring in extra nutrients to the site. Seabirds are known to supply large amount of nutrients, notably $\mathrm{P}$, to the neighbouring areas (Post and others 2008).

The most common underlying mechanisms of eutrophication in degrading seagrass are the direct toxic effects of ammonium (Santamaría and others 1994; van Katwijk and others 1997; Brun and others 2002; Govers and others 2014a) and the stimulation of algal growth including phytoplankton, macroalgae, and epiphytes (Duarte 1995; Burkholder and others 2007, 2008; Viaroli and others 2008). In our experiment, ammonium toxicity is the prime suspect in explaining the observed die-off at the exposed site, while (epiphytic) algal mats outcompeted seagrass at the more sheltered area. As these effects were already quite large, we do not expect that the effects would have been less if also the water column would have been fertilised.

\section{ACKNOWLEDGEMENTS}

We thank the direction of Parc National du Banc d'Arguin for granting the permission to conduct our study and to use the research vessel 'Théodore Monod'. We extend our sincere thanks to the scientific coordinator Lemhaba Yarba, the boat captain Mohamed Salem El Hadi and the skipper Mohamed Cheddad. We are grateful to the following multi-national team for their help in the field: Lenze Hofstee, Petra de Goeij, Greg Fivash, Puck Oomen, Mohamed Ahmed Sidi Cheikh, Sidi Yahya Lemrabott, Sall Amadou Abderahmane, Ruth Howison, Nynke-Rixt Jukema, Wytse Kamsma, Ahmed Sidi Mohamed, Ahmed Cheikhany Ould Lematt, Mamadou Ba Abdoul and Mohamed Brahim. We are particularly thankful for Amit Malhotra from NOAA, who patiently ran the WEMo model for us. Furthermore, we thank Sander Holthuijsen and Lennart van IJzerloo for their laboratory work. This research was funded and supported as a PhD project by MAVA foundation (Grant No. 12/126), Switzerland. Funding was provided by Rijksuniversiteit Groningen (Grant No. 190632083).

\section{OPEN ACCESS}

This article is distributed under the terms of the Creative Commons Attribution 4.0 International License (http://creativecommons.org/licenses/by/4 $.0 /$ ), which permits unrestricted use, distribution, and reproduction in any medium, provided you give appropriate credit to the original author(s) and the source, provide a link to the Creative Commons license, and indicate if changes were made. 


\section{REFERENCES}

Ahmedou OCA, Yasuda H, Wang K, Hattori K. 2008. Characteristics of precipitation in northern Mauritania and its links with sea surface temperature. J Arid Environ 72:2243-50.

Anderson WB, Polis GA. 1999. Nutrient fluxes from water to land: seabirds affect plant nutrient status on Gulf of California islands. Oecologia 118:324-32.

Armitage AR, Frankovich TA, Fourqurean JW. 2011. Long-term effects of adding nutrients to an oligotrophic coastal environment. Ecosystems 14:430-44.

Armitage AR, Frankovich TA, Heck KL, Fourqurean JW. 2005. Experimental nutrient enrichment causes complex changes in seagrass, microalgae, and macroalgae community structure in Florida Bay. Estuaries 28:422-34.

Baker AR, Jickells TD, Witt M, Linge KL. 2006. Trends in the solubility of iron, aluminium, manganese and phosphorus in aerosol collected over the Atlantic Ocean. Mar Chem 98:4358.

Balestri E, Lardicci C. 2014. Effects of sediment fertilization and burial on Cymodocea nodosa transplants; implications for seagrass restoration under a changing climate. Restor Ecol 22:240-7.

Bouma TJ, van Duren LA, Temmerman S, Claverie T, BlancoGarcia A, Ysebaert T, Herman PMJ. 2007. Spatial flow and sedimentation patterns within patches of epibenthic structures: combining field, flume and modelling experiments. Cont Shelf Res 27:1020-45.

Bouma TJ, De Vries MB, Low E, Peralta G, Tánczos IC, van de Koppel J, Herman PMJ. 2005. Trade-offs related to ecosystem engineering: a case study on stiffness of emerging macrophytes. Ecology 86:2187-99.

Brun F, Hernández I, Vergara J, Peralta G, Pérez-Lloréns J. 2002. Assessing the toxicity of ammonium pulses to the survival and growth of Zostera noltii. Mar Ecol Prog Ser 225:177-87.

Brun F, Vergara J, Navarro G, Hernández I, Pérez-Lloréns J. 2003. Effect of shading by Ulva rigida canopies on growth and carbon balance of the seagrass Zostera noltii. Mar Ecol Prog Ser 265:85-96.

Burdige DJ. 2006. Geochemistry of marine sediments. Princeton: Princeton University Press.

Burkholder D, Fourqurean J, Heithaus M. 2013. Spatial pattern in seagrass stoichiometry indicates both N-limited and P-limited regions of an iconic P-limited subtropical bay. Mar Ecol Prog Ser 472:101-15.

Burkholder JM, Cochlan WP, Gobler CJ, Heil CA, Kudela RM, Parsons ML, Rensel JEJ, Townsend DW, Trainer VL, Vargo GA. 2008. Harmful algal blooms and eutrophication: examining linkages from selected coastal regions of the United States. Harmful Algae 8:39-53.

Burkholder JM, Tomasko DA, Touchette BW. 2007. Seagrasses and eutrophication. J Exp Mar Biol Ecol 350:46-72.

Cabaço S, Machás R, Santos R. 2009. Individual and population plasticity of the seagrass Zostera noltii along a vertical intertidal gradient. Estuar Coast Shelf Sci 82:301-8.

Cabaço S, Santos R. 2007. Effects of burial and erosion on the seagrass Zostera noltii. J Exp Mar Biol Ecol 340:204-12.

Campredon P. 2000. Between the Sahara and the Atlantic: Banc d'Arguin National Park, Mauritania. Arles, La Tour du Valat: FIBA.
Cardoso PG, Raffaelli D, Pardal MA. 2008. The impact of extreme weather events on the seagrass Zostera noltii and related $H y$ drobia ulvae population. Mar Pollut Bull 56:483-92.

Carlier A, Chauvaud L, van der Geest M, Le Loc'h F, Le Duff M, Vernet M, Raffray J, Diakhaté D, Labrosse P, Wagué A, Le Goff C, Gohin F, Chapron B, Clavier J. 2015. Trophic connectivity between offshore upwelling and the inshore food web of Banc d'Arguin (Mauritania): new insights from isotopic analysis. Estuar Coast Shelf Sci 165:149-58.

Castillo S, Moreno T, Querol X, Alastuey A, Cuevas E, Herrmann L, Mounkaila M, Gibbons W. 2008. Trace element variation in size-fractionated African desert dusts. J Arid Environ 72:103445.

Castro P, Valiela I, Freitasa H. 2009. Sediment pool and plant content as indicators of nitrogen regimes in Portuguese estuaries. J Exp Mar Biol Ecol 380:1-10.

Christianen MJA, Govers LL, Bouma TJ, Kiswara W, Roelofs JGM, Lamers LPM, van Katwijk MM. 2012. Marine megaherbivore grazing may increase seagrass tolerance to high nutrient loads. J Ecol 100:546-60.

Clavier J, Chauvaud L, Carlier A, Amice E, van der Geest M, Labrosse P, Diagne A, Hily C. 2011. Aerial and underwater carbon metabolism of a Zostera noltii seagrass bed in the Banc d'Arguin, Mauritania. Aquat Bot 95:24-30.

Connell SD, Fernandes M, Burnell OW, Doubleday ZA, Griffin KJ, Irving AD, Leung JYS, Owen S, Russell BD, Falkenberg LJ. 2017. Testing for thresholds of ecosystem collapse in seagrass meadows. Conserv Biol 31:1196-201.

Cornelisen C, Thomas F. 2006. Water flow enhances ammonium and nitrate uptake in a seagrass community. Mar Ecol Prog Ser 312:1-13.

Cornelisen CD, Thomas FIM. 2004. Ammonium and nitrate uptake by leaves of the seagrass Thalassia testudinum: impact of hydrodynamic regime and epiphyte cover on uptake rates. J Mar Syst 49:177-94.

de Fouw J, Govers LL, van de Koppel J, van Belzen J, Dorigo W, Sidi Cheikh MA, Christianen MJA, van der Reijden KJ, van der Geest M, Piersma T, Smolders AJP, Olff H, Lamers LPM, van Gils JA, van der Heide T. 2016. Drought, mutualism breakdown, and landscape-scale degradation of seagrass beds. Curr Biol 26:1051-6.

Duarte CM. 1990. Seagrass nutrient content. Mar Ecol Prog Ser 67:201-7.

Duarte CM. 1995. Submerged aquatic vegetation in relation to different nutrient regimes. Ophelia 41:87-112.

Easterling DR, Meehl A, Parmesan C, Changnon S, Karl R, Mearns O. 2000. Climate extremes: observations, modeling, and impacts. Science 289:2068-74.

Folmer EO, van der Geest M, Jansen E, Olff H, Anderson M, Piersma T, van Gils JA. 2012. Seagrass-sediment feedback: an exploration using a non-recursive structural equation model. Ecosystems 15:1380-93.

Fonseca M, Bell S. 1998. Influence of physical setting on seagrass landscapes near Beaufort, North Carolina, USA. Mar Ecol Prog Ser 171:109-21.

Fourqurean JW, Marbà N, Duarte CM, Diaz-Almela E, RuizHalpern S. 2007. Spatial and temporal variation in the elemental and stable isotopic content of the seagrasses Posidonia oceanica and Cymodocea nodosa from the Illes Balears, Spain. Mar Biol 151:219-32. 
Fraser MW, Kendrick GA, Grierson PF, Fourqurean JW, Vanderklift MA, Walker DI. 2012. Nutrient status of seagrasses cannot be inferred from system-scale distribution of phosphorus in Shark Bay, Western Australia. Mar Freshw Res 63:1015-26.

Gabric AJ, Garcia L, van Camp L, Nykjaer L, Eifler W, Schrimpf W. 1993. Offshore export of shelf production in the Cape Blanc (Mauritania) giant filament as derived from coastal zone color scanner imagery. J Geophys Res 98:4697-712.

Goudie AS, Middleton NJ. 2001. Saharan dust storms: nature and consequences. Earth Sci Rev 56:179-204.

Govers LL, de Brouwer JHF, Suykerbuyk W, Bouma TJ, Lamers LPM, Smolders AJP, van Katwijk MM. 2014a. Toxic effects of increased sediment nutrient and organic matter loading on the seagrass Zostera noltii. Aquat Toxicol 155:253-60.

Govers LL, Lamers LPM, Bouma TJ, de Brouwer JHF, van Katwijk MM. 2014b. Eutrophication threatens Caribbean seagrasses-an example from Curaçao and Bonaire. Mar Pollut Bull 89:481-6.

Green PA, Vörösmarty CJ, Meybeck M, Galloway JN, Peterson BJ, Boyer EW. 2004. Pre-industrial and contemporary fluxes of nitrogen through rivers: a global assessment based on typology. Biogeochemistry 68:71-105.

Grice AM, Loneragan NR, Dennison WC. 1996. Light intensity and the interactions between physiology, morphology and stable isotope ratios in five species of seagrass. J Exp Mar Biol Ecol 195:91-110.

Grilo TF, Cardoso PG, Dolbeth M, Bordalo MD, Pardal MA. 2011. Effects of extreme climate events on the macrobenthic communities' structure and functioning of a temperate estuary. Mar Pollut Bull 62:303-11.

Hedges LV, Gurevitch J, Curtis PS. 1999. The meta-analysis of response ratios in experimental ecology. Ecology 80:1150-6.

Herbert DA, Fourqurean JW. 2009. Phosphorus availability and salinity control productivity and demography of the seagrass Thalassia testudinum in Florida Bay. Estuaries Coasts 32:188201.

Holmer M, Georgiev VG, Karamfilov VK. 2016. Effects of point source of untreated sewage waters on seagrass (Zostera marina and Z. noltii) beds in the South-Western Black Sea. Aquat Bot 133:1-9.

Hovey RK, Cambridge ML, Kendrick GA. 2012. Season and sediment nutrient additions affect root architecture in the temperate seagrasses Posidonia australis and P. sinuosa. Mar Ecol Prog Ser 446:23-30.

Hu Z, Lenting W, van der Wal D, Bouma TJ. 2015. Continuous monitoring bed-level dynamics on an intertidal flat: introducing novel, stand-alone high-resolution SED-sensors. Geomorphology 245:223-30.

Hu Z, van der Wal D, Cai H, van Belzen J, Bouma TJ. 2018. Dynamic equilibrium behaviour observed on two contrasting tidal flats from daily monitoring of bed-level changes. Geomorphology 311:114-26.

Hu Z, Yao P, van der Wal D, Bouma TJ. 2017. Patterns and drivers of daily bed-level dynamics on two tidal flats with contrasting wave exposure. Sci Rep 7:7088.

Huettel M. 2001. Porewater flow in permeable sediments. In: Boudrea BP, Jorgensen BB, Eds. The benthic boundary layer: transport processes and biogeochemistry. Oxford: Oxford University Press. p 144-79.
Hurd CL, Harrison PJ, Druehl LD. 1996. Effect of seawater velocity on inorganic nitrogen uptake by morphologically distinct forms of Macrocystis integrifolia from wave-sheltered and exposed sites. Mar Biol 126:205-14.

IPCC. 2012. Managing the risks of extreme events and disasters to advance climate change adaptation. In: Barros V, Stocker TF, Qin D, Dokken DJ, Ebi KL, Mastrandrea MD, Mach KJ, Allen SK, Tignor M, Eds. A special report of working groups I and II of the intergovernmental panel on climate change. Cambridge: Cambridge University Press. p 1-19.

Jagalingam P, Akshaya BJ, Hegde AV. 2015. Bathymetry mapping using Landsat 8 satellite imagery. Procedia Eng 116:5606.

Jager Z. 1993. The distribution and abundance of young fish in the Banc d'Arguin, Mauritania. Hydrobiologia 258:185-96.

Jeanson M, Dolique F, Anthony EJ. 2014. A GIS-based coastal monitoring and surveillance observatory on tropical islands exposed to climate change and extreme events: the example of Mayotte Island, Indian Ocean. J Coast Conserv 18:56780 .

Jentsch A, Kreyling J, Beierkuhnlein C. 2007. A new generation of climate-change experiments: events, not trends. Front Ecol Environ 5:365-74.

Jiménez-Ramos R, Mancilla M, Villazán B, Egea LG, GonzálezOrtiz V, Vergara JJ, Pérez-Lloréns JL, Brun FG. 2017. Resistance to nutrient enrichment varies among components in the Cymodocea nodosa community. J Exp Mar Biol Ecol 497:41-9.

Koch EW. 1994. Hydrodynamics, diffusion-boundary layers and photosynthesis of the seagrasses Thalassia testudinum and $\mathrm{Cy}$ modocea nodosa. Mar Biol 118:767-76.

Kramer J, Laan P, Sarthou G, Timmermans K, de Baar HJ. 2004. Distribution of dissolved aluminium in the high atmospheric input region of the subtropical waters of the North Atlantic Ocean. Mar Chem 88:85-101.

Lajeunesse MJ, Forbes MR. 2003. Variable reporting and quantitative reviews: a comparison of three meta-analytical techniques. Ecol Lett 6:448-54.

Legendre P, Legendre L. 1998. Numerical ecology. 2nd edn. Amsterdam: Elsevier.

Leoni V, Vela A, Pasqualini V, Pergent-Martini C, Pergent G. 2008. Effects of experimental reduction of light and nutrient enrichments ( $\mathrm{N}$ and $\mathrm{P}$ ) on seagrasses: a review. Aquat Conserv Mar Freshw Ecosyst 18:202-20.

Lepoint G, Dauby P, Fontaine M, Bouquegneau J-M, Gobert S. 2003. Carbon and nitrogen isotopic ratios of the seagrass Posidonia oceanica: depth-related variations. Bot Mar 46:55561.

Lepoint G, Dauby P, Gobert S. 2004. Applications of C and N stable isotopes to ecological and environmental studies in seagrass ecosystems. Mar Pollut Bull 49:887-91.

Lepš J, Šmilauer P. 2003. Multivariate analysis of ecological data using CANOCO. 1st edn. Cambridge: Cambridge University Press.

Malhotra A, Fonseca MS. 2007. WEMo (wave exposure model): formulation, procedures and validation. NOAA Technical Memorandum NOS NCCOS \#65.

Malta E, Stigter TY, Pacheco A, Dill AC, Tavares D, Santos R. 2017. Effects of external nutrient sources and extreme weather events on the nutrient budget of a southern European coastal lagoon. Estuaries Coasts 40:419-36. 
Marbà N, Duarte CM. 1995. Coupling of seagrass (Cymodocea nodosa) patch dynamics to subaqueous dune migration. J Ecol 83:381-9.

Marbà N, Hemminga M, Mateo M, Duarte M, Mass Y, Terrados J, Gacia E. 2002. Carbon and nitrogen translocation between seagrass ramets. Mar Ecol Prog Ser 226:287-300.

Marschner P. 2012. Marschner's mineral nutrition of higher plants. New York: Academic Press.

Maxwell PS, Eklöf JS, van Katwijk MM, O'Brien KR, de la TorreCastro M, Boström C, Bouma TJ, Krause-Jensen D, Unsworth RKF, van Tussenbroek BI, van der Heide T. 2017. The fundamental role of ecological feedback mechanisms for the adaptive management of seagrass ecosystems-a review. Biol Rev 92:1521-38.

Morris EP, Peralta G, Brun FG, van Duren L, Bouma TJ, PerezLlorens JL. 2008. Interaction between hydrodynamics and seagrass canopy structure: spatially explicit effects on ammonium uptake rates. Limnol Oceanogr 53:1531-9.

Morris EP, Peralta G, Van Engeland T, Bouma TJ, Brun FG, Lara M, Hendriks IE, Benavente J, Soetaert K, Middelburg JJ, Lucas Perez-Llorens J. 2013. The role of hydrodynamics in structuring in situ ammonium uptake within a submerged macrophyte community. Limnol Oceanogr Fluids Environ 3:210-24.

Neuer S, Torres-Padrón ME, Gelado-Caballero MD, Rueda MJ, Hernández-Brito J, Davenport R, Wefer G. 2004. Dust deposition pulses to the eastern subtropical North Atlantic gyre: does ocean's biogeochemistry respond? Global Biogeochem Cycles 18:1-10.

Orth RJ, Carruthers TJB, Dennison WC, Duarte CM, Fourqurean JW, Heck KL, Hughes AR, Kendrick GA, Kenworthy WJ, Olyarnik S, Short FT, Waycott M, Williams SL. 2006. A global crisis for seagrass ecosystems. Bioscience 56:987-96.

Östman Ö, Eklöf J, Eriksson BK, Olsson J, Moksnes P-O, Bergström U. 2016. Top-down control as important as nutrient enrichment for eutrophication effects in North Atlantic coastal ecosystems. J Appl Ecol 53:1138-47.

Ould Dedah S. 1993. Wind, surface water temperature, surface salinity and pollution in the area of the Banc d'Arguin, Mauritania. Hydrobiologia 258:9-19.

Paul M, Amos CL. 2011. Spatial and seasonal variation in wave attenuation over Zostera noltii. J Geophys Res Oceans 116:116.

Peralta G, Brun FG, Hernández I, Vergara JJ, Pérez-Lloréns JL. 2005. Morphometric variations as acclimation mechanisms in Zostera noltii beds. Estuar Coast Shelf Sci 64:347-56.

Peralta G, Brun FG, Pérez-Lloréns JL, Bouma TJ. 2006. Direct effects of current velocity on the growth, morphometry and architecture of seagrasses: a case study on Zostera noltii. Mar Ecol Prog Ser 327:135-42.

Peralta G, Pérez-Lloréns JL, Hernández I, Brun F, Vergara JJ, Bartual A, Gálvez JA, García CM. 2000. Morphological and physiological differences between two morphotypes of Zostera noltii Hornem. from the south-western Iberian Peninsula. Helgol Mar Res 54:80-6.

Pérez-Lloréns JL, Niell FX. 1993. Seasonal dynamics of biomass and nutrient content in the intertidal seagrass Zostera noltii Hornem. from Palmones River estuary, Spain. Aquat Bot 46:49-66.

Pergent-Martini C, Pasqualini V, Ferrat L, Pergent G, Fernandez C. 2005. Seasonal dynamics of Zostera noltii Hornem. in two Mediterranean lagoons. Hydrobiologia 543:233-43.
Post DM, Taylor JP, Kitchell JF, Olson MH, Schindler DE, Herwig BR. 2008. The role of migratory waterfowl as nutrient vectors in a managed wetland. Conserv Biol 12:910-20.

Ruesink JL, Yang S, Trimble AC. 2015. Variability in carbon availability and eelgrass (Zostera marina) biometrics along an estuarine gradient in Willapa Bay, WA, USA. Estuaries Coasts 38:1908-17.

Santamaría L, Dias C, Hootsmans MJM. 1994. The influence of ammonia on the growth and photosynthesis of Ruppia drepanensis Tineo from Doniana National Park (SW Spain). Hydrobiologia 275-276:219-31.

Santos IR, Eyre BD, Huettel M. 2012. The driving forces of porewater and groundwater flow in permeable coastal sediments: a review. Estuar Coast Shelf Sci 98:1-15.

Schrama M, Jouta J, Berg MP, Olff H. 2013. Food web assembly at the landscape scale: using stable isotopes to reveal changes in trophic structure during succession. Ecosystems 16:627-38.

Sevrin-Reyssac J. 1993. Hydrology and underwater climate of the Banc d'Arguin, Mauritania: a review. Hydrobiologia 258:1-8.

Short FT, Burdick DM, Kaldy JE. 1995. Mesocosm experiments quantify the effects of eutrophication on eelgrass, Zostera marina. Limnol Oceanogr 40:740-9.

Short FT, Wyllie-Echeverria S. 1996. Natural and human-induced disturbance of seagrasses. Environ Conserv 23:1727.

Steinfeldt R, Sültenfuß J, Dengler M, Fischer T, Rhein M. 2015. Coastal upwelling off Peru and Mauritania inferred from helium isotope disequilibrium. Biogeosciences 12:7519-33.

Suykerbuyk W, Bouma TJ, Govers LL, Giesen K, de Jong DJ, Herman P, Hendriks J, van Katwijk MM. 2016. Surviving in changing seascapes: sediment dynamics as bottleneck for long-term seagrass presence. Ecosystems 19:296-310.

Thomas FIM, Cornelisen CD, Zande JM. 2000. Effects of water velocity and canopy morphology on ammonium uptake by seagrass communities. Ecology 81:2704-13.

Touchette Burkholder. 2000. Review of nitrogen and phosphorus metabolism in seagrasses. J Exp Mar Biol Ecol 250:13367.

Turner SJ, Hewitt JE, Wilkinson MR, Morrisey DJ, Thrush SF, Cummings VJ, Funnell GA. 1999. Seagrass patches and landscapes: the influence of wind-wave dynamics and hierarchical arrangements of spatial structure on macrofaunal seagrass communities. Estuaries 22:1016-32.

Vacchi M, Montefalcone M, Bianchi CN, Morri C, Ferrari M. 2012. Hydrodynamic constraints to the seaward development of Posidonia oceanica meadows. Estuar Coast Shelf Sci 97:5865.

van der Heide T, van Nes EH, Geerling GW, Smolders AJP, Bouma TJ, van Katwijk MM. 2007. Positive feedbacks in seagrass ecosystems: implications for success in conservation and restoration. Ecosystems 10:1311-22.

van der Heide T, Smolders AJP, Rijkens BGA, van Nes EH, van Katwijk MM, Roelofs JGM. 2008. Toxicity of reduced nitrogen in eelgrass (Zostera marina) is highly dependent on shoot density and pH. Oecologia 158:411-19.

van Katwijk MM, Hermus DCR. 2000. Effects of water dynamics on Zostera marina: transplantation experiments in the intertidal Dutch Wadden Sea. Mar Ecol Prog Ser 208:107-18.

van Katwijk MM, Vergeer LHT, Schmitz GHW, Roelofs JGM. 1997. Ammonium toxicity in eelgrass Zostera marina. Mar Ecol Prog Ser 157:159-73. 
Vermaat JE, Verhagen FCA. 1996. Seasonal variation in the intertidal seagrass Zostera noltii Hornem.: coupling demographic and physiological patterns. Aquat Bot 52:259-81.

Viaroli P, Bartoli M, Giordani G, Naldi M, Orfanidis S, Zaldivar JM. 2008. Community shifts, alternative stable states, biogeochemical controls and feedbacks in eutrophic coastal lagoons: a brief overview. Aquat Conserv Mar Freshw Ecosyst 18:S105-17.

Viechtbauer W. 2010. Conducting meta-analyses in R with the metafor package. J Stat Softw 36:1-48.
Waycott M, Duarte CM, Carruthers TJB, Orth RJ, Dennison WC, Olyarnik S, Calladine A, Fourqurean JW, Heck KL, Hughes AR, Kendrick GA, Kenworthy WJ, Short FT, Williams SL. 2009. Accelerating loss of seagrasses across the globe threatens coastal ecosystems. Proc Natl Acad Sci USA 106:12377-81.

Wolff WJ, van der Land J, Nienhuis PH, de Wilde PAWJ. 1993. The functioning of the ecosystem of the Banc d'Arguin, Mauritania: a review. Hydrobiologia 258:211-22.

Wolff WJ, Smit CJ. 1990. The Banc d'Arguin, Mauritania, as an environment for coastal birds. Ardea 78:17-38. 